Tropical Journal of Pharmaceutical Research October 2021; 20 (10): 2055-2062

ISSN: $1596-5996$ (print); 1596-9827 (electronic) (C) Pharmacotherapy Group, Faculty of Pharmacy, University of Benin, Benin City, 300001 Nigeria.

\title{
Fasudil ameliorated liposaccharide-induced acute kidney injury in mice by inhibiting NLRP3
}

\author{
Xueqian $\mathrm{Li}^{*}$, Chengzhi Zhao \\ Hebi Polytechnic, Hebi, Henan, 458030, China \\ *For correspondence: Email: qyyh1a@163.com; Tel: +86-457-13938009597
}

Sent for review: 17 July 2021

Revised accepted: 2 October 2021

\begin{abstract}
Purpose: To determine the influence of fasudil on LPS-mediated acute kidney injury (AKI) in mice. Methods: Healthy C57 mice $(n=140)$ of largely similar weight were used in this study. They were assigned to a treatment group $(n=40)$, a model group $(n=50)$, and a blank control group $(n=50)$. Mice in treatment and model groups were injected with lipopolysaccharide (LPS). In the treatment group, each mouse was injected intravenously with fasudil daily before the establishment of the mouse model of AKI. All mice were sacrificed $6 \mathrm{~h}$ after establishing the AKI model. Portions of the kidney from mice were used for preparation of tissue homogenates, while the remaining portions were subjected to primary culture. Transformed C3H Mouse Kidney-1 (TCMK1) and mesangial cells from mouse glomeruli (SV40-MES-13) cells were used for assays of cell growth and apoptosis. Blood samples were also collected from the mice. Thereafter, the levels of blood urea nitrogen (BUN) and creatinine $(\mathrm{Cr})$ in kidney homogenates of the three groups were determined. Moreover, levels of NLRP3, nuclear factor kappa-B (NF-KB), toll-like receptor 4 (TLR4), tumor necrosis factor- $\alpha$ (TNF- $\alpha$ ), interleukin (IL)-6, and IL$1 \beta$ in the homogenates and blood were assayed. Cell growth and apoptosis were also measured. Results: The treatment group and model group showed higher levels of BUN and Cr than the control group, with a higher level observed in model mice than in the treatment mice. There were significantly higher relative levels of NF-KB, NLRP3 and TLR4 in treatment and model groups than in controls, with a higher level observed in model mice than in treatment mice. There were significantly higher concentrations of inflammatory factors in treatment and model mice groups than in control mice, with higher levels observed in model mice than in treatment mice. The TCMK1 and SV40-MES-13 cells in the two groups showed slower cell growth and stronger apoptosis than those in control group $(p<0.05)$. Conclusion: Fasudil relieved LPS-mediated AKI in mice by suppressing TLR4/NF-KB signal pathway and lowering NLRP3. Thus, fasudil has potential as a new adjunctive agent for the treatment of AKI.
\end{abstract}

Keywords: Acute kidney injury, Fasudil, NLRP3, Lipopolysaccharide, Blood urea nitrogen, Creatinine

\begin{abstract}
This is an Open Access article that uses a funding model which does not charge readers or their institutions for access and distributed under the terms of the Creative Commons Attribution License (http://creativecommons.org/licenses/by/4.0) and the Budapest Open Access Initiative (http://www.budapestopenaccessinitiative.org/read), which permit unrestricted use, distribution, and reproduction in any medium, provided the original work is properly credited.
\end{abstract}

Tropical Journal of Pharmaceutical Research is indexed by Science Citation Index (SciSearch), Scopus, International Pharmaceutical Abstract, Chemical Abstracts, Embase, Index Copernicus, EBSCO, African Index Medicus, JournalSeek, Journal Citation Reports/Science Edition, Directory of Open Access Journals (DOAJ), African Journal Online, Bioline International, Open-J-Gate and Pharmacy Abstracts

\section{INTRODUCTION}

Acute kidney injury (AKI) is closely associated with progressive loss of kidney function, and cardiovascular disease [1]. The morbidity and mortality rates due to $\mathrm{AKI}$ are on the rise, with up to $57 \%$ of critically-ill patients suffering from the disease [2, 3]. Extracorporeal circulation associated with AKI may trigger systemic inflammatory response and a cascade of adverse 
clinical outcomes [4]. Therefore, appropriate treatment method is crucial for the management of $\mathrm{AKI}$.

Lipopolysaccharide (LPS) is one of the current reagents used in research on AKI-related target molecules. It is the outer membrane component of Gram-ve bacteria, and it is a key contributor to AKI. It binds to TLR4 and induces the release of inflammatory cytokines i.e., tumor necrosis factor- $\alpha$ (TNF- $\alpha$ ), interleukin (IL)-6, and IL-1 $\beta$ in the nucleus by recruiting transcription factor such as nuclear factor-kB (NF-kB), thereby causing more severe kidney disease [5,6]. In addition, LPS-mediated regulation of NLRP3 inflammasome containing the PYD structural domain plays a key role in the pathogenesis of inflammation [7, 8]. Increases in levels of NLRP3, TLR4 and NF-KB imply exacerbation of AKI [9]. Fasudil, an anti-inflammatory drug which belongs to the isoquinoline derivatives, was originally developed as a vasodilator [10]. It is widely used in treating cardiovascular diseases. However, very few studies are available on the effect of fasudil on $\mathrm{AKI}$, and its influence on factors such as NLRP3 and LP.

Therefore, this study was conducted in mouse AKI model to determine the impact of fasudil on NLRP3 and LPS.

\section{EXPERIMENTAL}

\section{Animal models, reagents, and instruments}

A total of 140 healthy C57 mice obtained from Hunan STA Laboratory Animal Co. Ltd were used in this study. The mice were comparable with respect to age, body length, weight and feeding conditions. This study was approved by the Animal Ethics Committee of Hebi Polytechnic (approval no. AM68792HU). The animal experiments were carried out in line with the "Laboratory Animal Guidelines for Ethical Review of Animal Welfare" [11].

The reagents used in this study, and their sources (in brackets) were: $0.25 \%$ trypsin (Life technologies, USA); PBS (Thermo Fisher Scientific, CN); western blotting (WB) kits (Yiyan Biotechnology Co. Ltd, Shanghai, CN); ELISA kits (Yansheng Biochemical Reagent Co. Ltd, Shanghai, CN); LPS (Escherichia coli 055: B5; $100 \mathrm{mg}$, Sigma, USA); fasudil injection [State Food and Drug Administration (SFDA); approval number: $\mathrm{H} 20040356$, Chase Sun Pharmaceutical Co. Ltd, Tianjin, CN]; TBST (Biolab Technology Co. Ltd, Beijing, CN); loading buffer (Beyotime Biotechnology Research Institute); xylene, ethanol, hematoxylin, eosin and neutral balsam
(Sigma, USA); BCA protein concentration determination kit (Beyotime Biotechnology Research Institute); NC membrane (Amresco); cell cycle detection kit (MLBIO Co. Ltd, Shanghai, CN); CCK8 kit (Jingkang Bioengineering Co. Ltd, Shanghai, China), and transfection reagents of apoptosis detection kit.

The equipment used in this study, and their suppliers (in brackets) were as follows: incubator (Feiyue Experiment Instrument Co. Ltd, Shanghai, CN); full-wavelength microplate reader (All Sheng Instrument Co. Ltd, Hangzhou, CN), and tissue homogenizer (Medical Instrument Factory, Shanghai, CN).

\section{Establishment of mouse model of AKI, animal grouping, and tissue processing}

All the 140 mice were acclimatized to laboratory conditions and fed for 1 week. Three mice groups were used: blank control $(n=50)$, treatment $(n=40)$, and model $(n=50)$ groups. In the treatment group, each mouse was given daily intravenous injection of fasudil $(30 \mathrm{mg} / \mathrm{kg})$ for 3 consecutive days before establishment of the AKI model via intravenous injection of LPS (6 $\mathrm{mg} / \mathrm{kg}$ ). In the model group, each mouse was injected with an equivalent dose of normal saline each day before the establishment of animal model, prior to intravenous injection of LPS (6 $\mathrm{mg} / \mathrm{kg}$ ) to establish the AKI model. In the three groups, each mouse was fasted for $12 \mathrm{~h}$ before establishment of the AKI model, and sacrificed 6 $\mathrm{h}$ after establishing the model. Blood was sampled from each mouse for the measurement of blood urea nitrogen and creatinine.

Samples of kidney tissues were taken from each mouse and washed 3 times with normal saline. Portions of the kidney tissues were used to prepare tissue homogenates. In essence, the tissues were washed, blotted with filter paper, weighed and transferred to a homogenization tube containing normal saline. The ratio of tissue to saline was 1:9 (weight: volume). The tissue was homogenized 3-5 consecutive times, each for $10 \mathrm{sec}$ at intervals of $30 \mathrm{sec}$, using a homogenizer in a medium of ice-cold water. The homogenate was subjected to 10-min centrifugation at $1500 \mathrm{~g}$ at $4{ }^{\circ} \mathrm{C}$ using a lowtemperature and low-speed centrifuge. The supernatant was obtained was used for the determination of levels of NLRP3, TLR4, and NF$\mathrm{KB}$. The remaining kidney portion was subjected to primary culture. Transformed $\mathrm{C} 3 \mathrm{H}$ Mouse Kidney-1 (TCMK1) and SV40-MES-13 cells were subjected to assays for cell growth and apoptosis.

\section{Assay of serum parameters using ELISA}


Peripheral blood of mice was collected in EDTA anticoagulant tubes, mixed for $10-20 \mathrm{~min}$, and centrifuged at $3000 \mathrm{rpm}$ for $20 \mathrm{~min}$. The supernatant was collected. Kidney tissue homogenates were also prepared. The levels of TNF- $\alpha$, BUN, Cr, IL-6 and IL-1 $\beta$ were assayed with their ELISA kits.

\section{Western blot of NLRP3, NF-KB, and TLR4}

The levels of NLRP3, NF-KB, and TLR4 in blood and kidney homogenates in the three groups were determined using western blotting (WB). The protein expression levels were determined in relation to that of GADPH which served as internal standard.

\section{Assessment of cell proliferation}

A suspension prepared from the cultured cells was transferred to a 96-well plate $(100 \mu \mathrm{l} /$ well. Experiments in each well were conducted in duplicate. The cells were subjected to culture for 24,48 and $72 \mathrm{~h}$, followed by the addition of CCK8 after 22 h, $46 \mathrm{~h}$ and $70 \mathrm{~h}$ of each culture. Then, the plate was placed in a $5 \% \mathrm{CO}_{2}$ cell incubator at $37^{\circ} \mathrm{C}$ for $2 \mathrm{~h}$ prior to evaluation of cell proliferation through measurement of optical density of every well in an automatic microplate reader at $490 \mathrm{~nm}$. The evaluation of cell proliferation was done in triplicate.

\section{Determination of apoptosis}

Apoptosis in the three groups was determined using flow cytometric analysis. After 48-h transfection and staining with Annexin $\mathrm{V}$ and $\mathrm{PI}$, the apoptosis of cells inoculated in a 6-well plate was determined using a BD FACS Calibur flow cytometer (PuDi Biotech Co. Ltd., Shanghai, $\mathrm{CN})$. The experiment was repeated three times.

\section{Statistical analysis}

The SPSS 25.0 (Asia Analytics, formerly SPSS China) was used for statistical analyses of data. This study adopted mixed methods for statistical analysis: chi-squared $\left(x^{2}\right)$ test, one-way ANOVA, and $t$-test. Count data on mouse sex were analyzed using $x^{2}$ test, while measurement data, presented as mean \pm SD, were compared among the three groups at three different times using one-way ANOVA test, and at two different times using independent sample $t$-test. Values of $p<$ 0.05 indicated significant differences.

Table 1: Comparison of general mouse characteristics

\section{RESULTS}

\section{General mice characteristics}

General data were comparable, with no significant differences among the three groups, regarding weight, age and length $(p>0.05$, Table 1).

\section{Blood BUN and $\mathrm{Cr}$}

Figure 1 shows that mice in treatment and model groups had more BUN and $\mathrm{Cr}$ than the control group, with significantly higher outcomes observed in model mice than in treatment group.
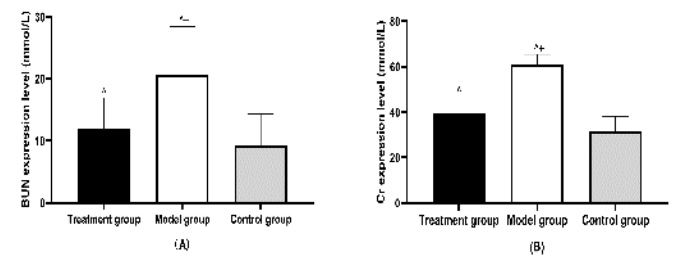

Figure 1: Serum levels of BUN and Cr. ${ }^{\wedge} P<0.05$, vs control; $+p<0.05$, vs treatment mice

\section{Relative expression levels of NLRP3, NF-kB, and TLR4 in homogenates}

Significantly higher relative levels of NLRP3, NF$\mathrm{KB}$ and TLR4 were observed in model and treatment mice than in control mice, but the model group had higher levels of these indicators than the treatment group ( $p<0.05$; Figure 2).

\section{Relative expression levels of NLRP3, NF-kB, and TLR4 in blood}

Figure 3 shows that treatment mice and model group had significantly higher relative levels of NLRP3, NF-kB and TLR4 than the control group, with model mice having higher amounts of the above indicators than treatment mice.

\section{Levels of TNF- $\alpha$, IL- 6 , and IL-1 $1 \beta$ in kidney homogenates}

Figure 4 shows that model mice had the highest amounts of TNF- $\alpha, \mathrm{IL}-6$ and IL- $1 \beta$, followed by the treatment group, and then the control group.

\section{Levels of TNF- $\alpha$, IL- 6 , and IL-1 $\beta$ in blood}

As shown in Figure 5, the treatment group and model group had markedly up-regulated TNF- $\alpha$, IL-6 and IL-1 $\beta$, relative to the control group, with significantly higher levels in model mice than in treatment mice.

Trop J Pharm Res, October 2021; 20(10): 2057 


\begin{tabular}{|c|c|c|c|c|c|c|}
\hline Group & $\begin{array}{l}\text { Gender } \\
\text { (M/F) }\end{array}$ & $\begin{array}{c}\text { Weight } \\
\text { (mean } \pm S D, \\
\text { g) }\end{array}$ & $\begin{array}{c}\text { Age } \\
\text { (mean } \pm S D, \\
\text { day) }\end{array}$ & $\begin{array}{c}\text { Length } \\
\text { (mean } \pm S D, \\
\text { cm) }\end{array}$ & $\begin{array}{l}\text { Temperature } \\
\left(\text { mean } \pm S D,{ }^{\circ} \mathrm{C}\right)\end{array}$ & $\begin{array}{c}\text { Relative } \\
\text { humidity } \\
\text { (mean } \pm \text { SD, \%) }\end{array}$ \\
\hline $\begin{array}{l}\text { Treatment } \\
(\mathrm{n}=40)\end{array}$ & $27 / 13$ & $19.87 \pm 1.04$ & $47.04 \pm 7.73$ & $10.16 \pm 0.92$ & $24.76 \pm 1.42$ & $50.13 \pm 11.32$ \\
\hline $\begin{array}{l}\text { Model } \\
(n=50)\end{array}$ & $32 / 18$ & $20.24 \pm 0.96$ & $46.84 \pm 8.03$ & $9.97 \pm 1.22$ & $24.88 \pm 1.37$ & $49.97 \pm 12.42$ \\
\hline $\begin{array}{l}\text { Control } \\
(n=50)\end{array}$ & $28 / 22$ & $19.98 \pm 1.02$ & $47.22 \pm 7.99$ & $9.96 \pm 1.32$ & $24.93 \pm 1.34$ & $49.82 \pm 10.45$ \\
\hline $\begin{array}{l}\mathrm{F} / \mathrm{X}^{2} \\
P \text {-value }\end{array}$ & $\begin{array}{l}1.36 \\
0.506\end{array}$ & $\begin{array}{c}1.65 \\
0.196\end{array}$ & $\begin{array}{c}0.02 \\
0.971\end{array}$ & $\begin{array}{c}0.39 \\
0.678\end{array}$ & $\begin{array}{c}0.18 \\
0.839\end{array}$ & $\begin{array}{c}0.01 \\
0.992\end{array}$ \\
\hline
\end{tabular}

\section{Cell proliferation}

\section{TCMK1 cells}

As shown in Table 2, the three groups had marked elevations in the number of TCMK1 cells at $48 \mathrm{~h}$ and $72 \mathrm{~h}$, with the greatest degree of increase observed in the control group, followed by mice in treatment and model groups.

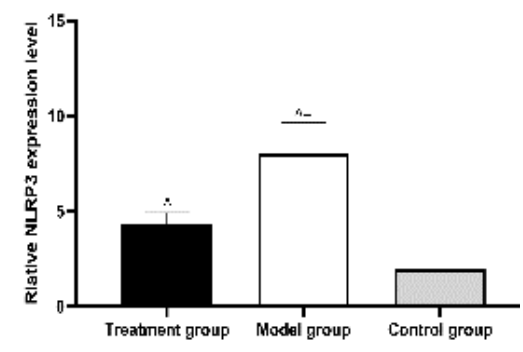

(A)

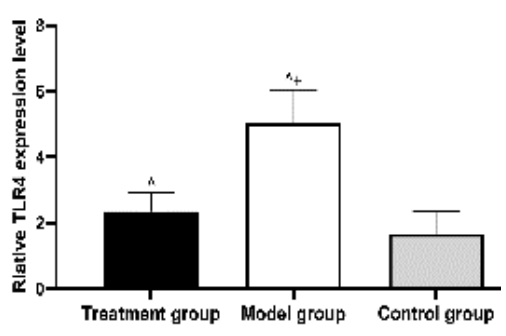

(B)

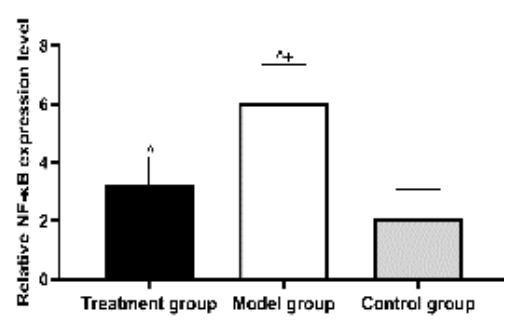

(C)

Figure 2: Relative amounts of NLRP3, NF-KB and TLR4 proteins in kidney homogenates. ${ }^{\wedge} P<0.05$, vs control; $+p<0.05$, vs treatment

As shown in Table 3, the three groups had significant elevations in the number of SV40-
MES- 13 cells at $48 \mathrm{~h}$ and $72 \mathrm{~h}$, with the greatest degree of increase observed in the control group, followed by mice in treatment and then model groups.

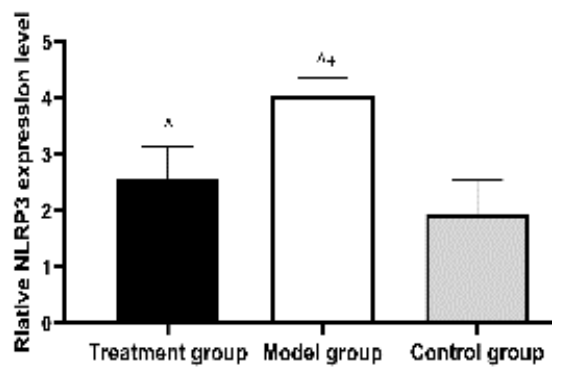

(A)

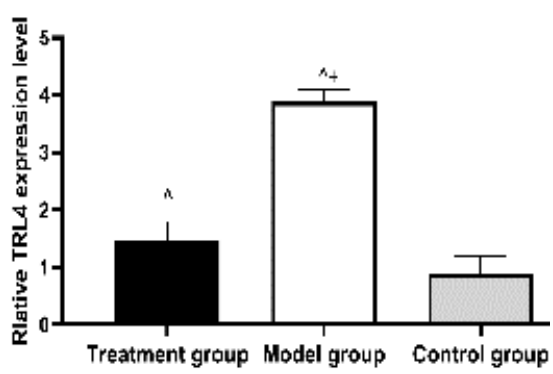

(B)

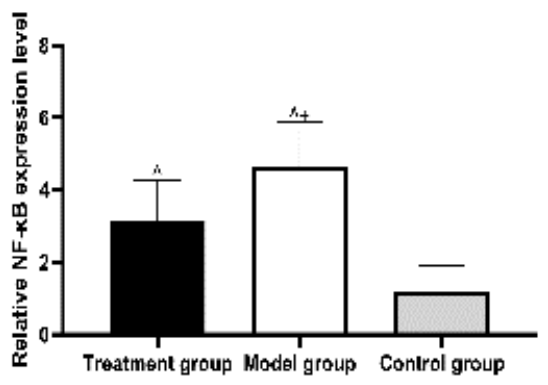

(C)

Figure 3: Relative levels of NLRP3, NF-KB, and TLR4 in blood. ${ }^{\wedge} P<0.05$, relative to control; $+p<0.05$, relative to treatment mice

Trop J Pharm Res, October 2021; 20(10): 2058 


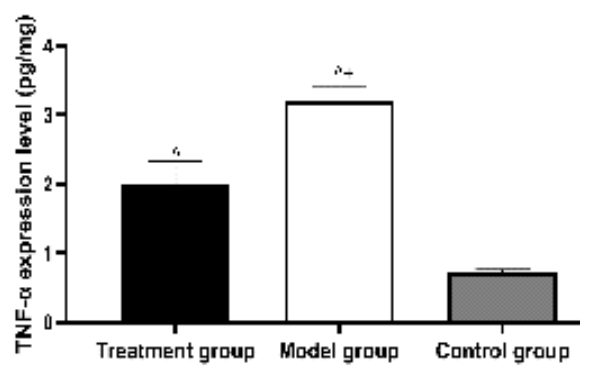

(A)

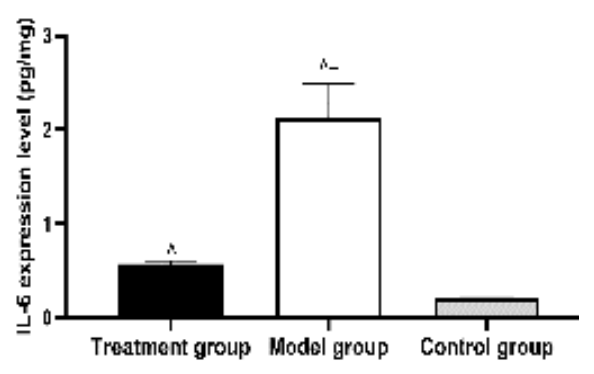

(B)

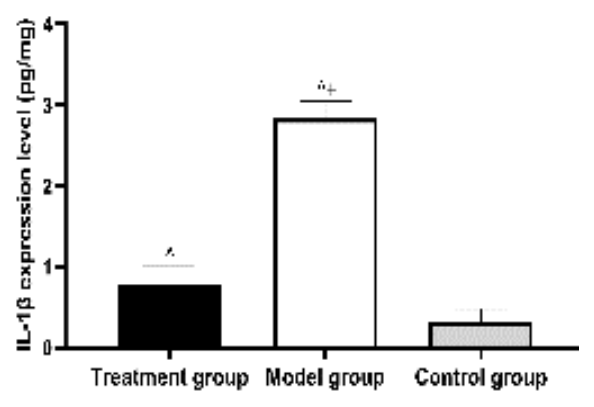

(c)

Figure 4: Amounts of inflammatory factors in homogenates. ${ }^{\wedge} P<0.05$, relative to control; $+p<0.05$, relative to treatment

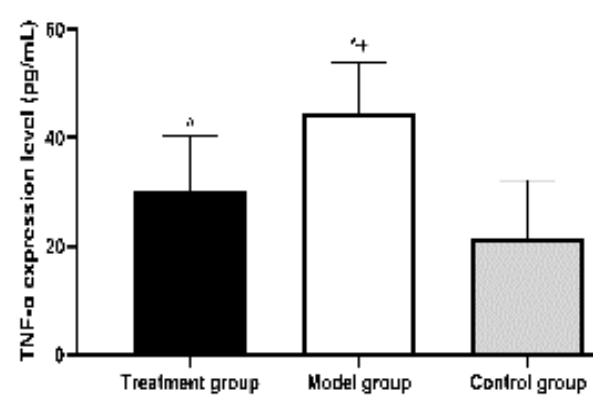

\{A]

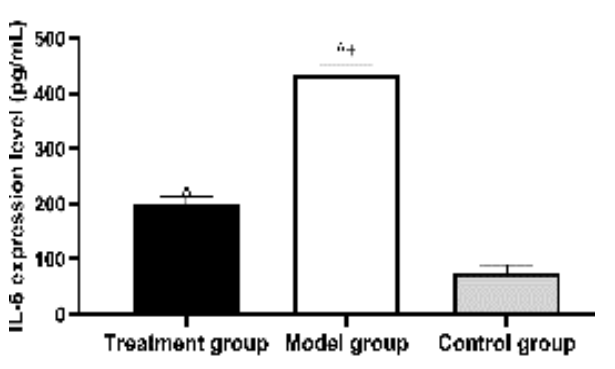

(B)

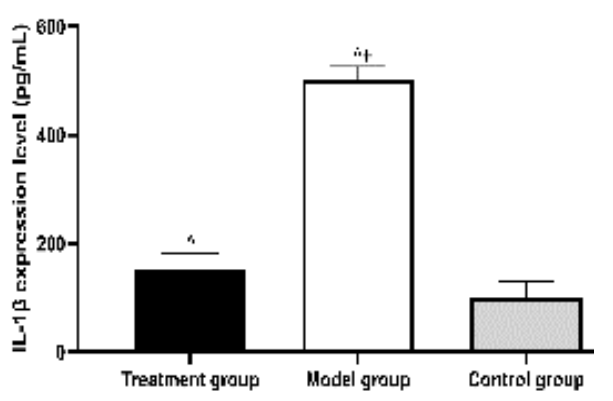

〈G)

Figure 5: Blood levels of inflammatory factors. ${ }^{\wedge} P<$ 0.05 , vs control; $+p<0.05$, vs treatment mice

Table 2: Growth of TCMK1 cells

\begin{tabular}{lccc}
\hline Group & $\mathbf{2 4} \mathbf{~ h}$ & $\mathbf{4 8} \mathbf{~}$ & $\mathbf{7 2} \mathbf{~}$ \\
\hline Treatment $(\mathrm{n}=40)$ & $1.02 \pm 0.43$ & $3.65 \pm 0.23^{*}$ & $5.57 \pm 1.34^{\star} \#$ \\
Model $(\mathrm{n}=50)$ & $1.05 \pm 0.41$ & $2.74 \pm 0.57^{*}$ & $3.54 \pm 0.92^{\star} \#$ \\
Control $(\mathrm{n}=50)$ & $1.06 \pm 0.39$ & $4.71 \pm 1.65^{*}$ & $6.91 \pm 1.72^{\star} \#$ \\
$F$ & 0.11 & 43.97 & 76.74 \\
$P$-value & 0.894 & $<0.001$ & $<0.001$ \\
\hline
\end{tabular}

${ }^{*} P<0.05$ vs. $24 \mathrm{~h}$ later; $\# p<0.05$ vs. $48 \mathrm{~h}$ later

Table 3: Proliferation of SV40-MES-13 cells

\begin{tabular}{lccc}
\hline Group & $\mathbf{2 4} \mathbf{~}$ & $\mathbf{4 8} \mathbf{~ h}$ & $\mathbf{7 2} \mathbf{~}$ \\
\hline Treatment $(\mathrm{n}=40)$ & $0.77 \pm 0.21$ & $1.98 \pm 0.23^{*}$ & $4.55 \pm 0.67^{\star} \#$ \\
Model $(\mathrm{n}=50)$ & $0.76 \pm 0.23$ & $1.25 \pm 0.19^{*}$ & $3.11 \pm 0.44^{*} \#$ \\
Control $(\mathrm{n}=50)$ & $0.78 \pm 0.20$ & $3.67 \pm 0.27^{*}$ & $6.86 \pm 0.82^{\star} \#$ \\
$F$ & 0.1 & 1287 & 407.9 \\
$P$-value & 0.897 & $<0.001$ & $<0.001$ \\
\hline
\end{tabular}

${ }^{\star} P<0.05$ vs. 24 h later; $\# p<0.05$ vs. after 48 h 
Table 4: Apoptosis of TCMK1 and SV40-MES-13 cells

\begin{tabular}{lcc}
\hline Group & TCMK1 & SV40-MES-13 \\
\hline Treatment $(\mathrm{n}=40)$ & $5.38 \pm 1.53$ & $6.28 \pm 1.47$ \\
Model $(\mathrm{n}=50)$ & $15.78 \pm 2.51^{*}$ & $10.66 \pm 1.87^{*}$ \\
Control $(\mathrm{n}=50)$ & $3.87 \pm 1.46^{\star} \#$ & $4.32 \pm 1.88^{*} \#$ \\
$F$ & 558.2 & 167.2 \\
$P$-value & $<0.001$ & $<0.001$ \\
\hline${ }^{*} P<0.05$, vs treatment; $\# p<0.05$ vs. model
\end{tabular}

\section{Apoptosis}

Table 4 shows that the strongest apoptosis was observed in the model group, followed by treatment and control groups.

\section{DISCUSSION}

Lipopolysaccharide may easily cause significant damage to organs, leading to marked increases in the levels of inflammatory markers and impairment of kidney function, which are considered major causes of AKI [12-14]. Therefore, in this study, the impact of fasudil on AKI mice was determined with respect to levels of BUN, $\mathrm{Cr}$ and NLRP3 which are important indicators. After treatment, the model and the treatment groups had markedly higher amounts of BUN and $\mathrm{Cr}$ than the control group. Moreover, the model and treatment groups had slower growth and stronger apoptosis than the control group. It has been reported that $\mathrm{BUN}$ and $\mathrm{Cr}$ are risk factors for AKI [15].

Previous studies have also indicated that increases in BUN and $\mathrm{Cr}$ are detrimental to kidney function $[16,17]$. This is consistent with the impaired renal function in mice in the treatment group and the model group after exposure to LPS in this study. However, after treatment with fasudil, the treatment group had lower $\mathrm{BUN}$ and $\mathrm{Cr}$ than the model group, while TCMK1 and SV40-MES-13 cells from the treatment group showed better growth and lower apoptosis than those from the model group. It has been reported that fasudil restored kidney function by inhibiting apoptosis of glomerulus and renal tubules, as well as ameliorating redox imbalance and DNA damage [18].

Moreover, another study [19] demonstrated that the use of fasudil alleviated kidney injury. In the present study, the treatment group showed lowered degree of apoptosis and decreases in levels of BUN and $\mathrm{Cr}$, when compared with the model group. These results indicate that fasudil restored kidney function by alleviating apoptosis of kidney cells such as glomerular and tubular cells.

It has been shown that in cases of LPS-induced AKI, the TLR4/NF-KB signal route is activated, while the NLRP3 inflammasome is up-regulated. Inhibition of the TLR4/NF-KB pathway suppressed NLRP3 inflammasome in kidney tissue and inhibited inflammatory response and oxidative stress, thereby protecting the kidney cells $[20,21]$. In one study on the effect of Huangkui capsule on diabetic nephropathy, it was found that the capsule alleviated inflammatory response in kidney tissue by suppressing the activation of NLRP3 inflammasome and blocking TLR4/NF-KB signal transduction, thereby promoting effective recovery of kidney function [22]. In another research on AKI in mice, it was found that harmine lowered NLRP3 inflammasome by suppressing the TLR4/NF-KB signal route, and alleviated oxidative stress and inflammatory reaction, thereby protecting the mice from further aggravation of LPS-mediated AKI [23].

These results are in agreement with the findings in the present investigation which showed that fasudil lowered NLRP3 inflammasome in AKI mice. Moreover, fasudil reduced the expression levels of several proteins involved in inflammation, thereby inhibiting the TLR4/ NF-KB pathway. Thus, it alleviated inflammatory reactions, reduced apoptosis of kidney cells, and restored kidney function.

\section{Limitations of the study}

The limitations of this study lie in the absence of investigations on the effect of different doses of fasudil on AKI mice, due to small sample size, as well as absence of a more in-depth study on the molecular mechanisms involved. These limitations will be remedied in future studies in order to provide more accurate information to guide clinical treatment of AKI.

\section{CONCLUSION}

Fasudil ameliorated LPS-mediated AKI in mice by suppressing the TLR4/NF-KB signal route and lowering NLRP3. Thus, this compound can be potentially developed into a drug for the treatment of AKI.

Trop J Pharm Res, October 2021; 20(10): 2060 


\section{DECLARATIONS}

\section{Conflict of Interest}

No conflict of interest associated with this work.

\section{Contribution of Authors}

We declare that this work was done by the authors named in this article, and all liabilities pertaining to claims relating to the content of this article will be borne by the authors. Xueqian Li and Chengzhi Zhao conceived and designed the study, collected, analyzed and interpreted the experimental data, drafted the manuscript, and revised the manuscript for important intellectual content. All authors read and approved the final manuscript.

\section{Open Access}

This is an Open Access article that uses a funding model which does not charge readers or their institutions for access and distributed under the terms of the Creative Commons Attribution License (http://creativecommons.org/licenses/by/ 4.0) and the Budapest Open Access Initiative (http://www.budapestopenaccessinitiative.org/rea d), which permit unrestricted use, distribution, and reproduction in any medium, provided the original work is properly credited.

\section{REFERENCES}

1. Hsu RK, McCulloch CE, Heung M, Saran R, Shahinian VB, Pavkov ME, Burrows NR, Powe NR, Hsu CY, Centers for Disease Control and Prevention Chronic Kidney Disease Surveillance T. Exploring Potential Reasons for the Temporal Trend in Dialysis-Requiring AKI in the United States. Clin J Am Soc Nephrol 2016; 11: 14-20.

2. Malhotra R, Siew ED. Biomarkers for the Early Detection and Prognosis of Acute Kidney Injury. Clin J Am Soc Nephrol 2017; 12: 149-173.

3. Hoste EA, Bagshaw SM, Bellomo R, Cely CM, Colman R, Cruz DN, Edipidis K, Forni $L G$, Gomersall $C D$, Govil $D$, et al. Epidemiology of acute kidney injury in critically ill patients: the multinational AKI-EPI study. Intensive Care Med 2015; 41: 1411-1423.

4. Garg AX, Chan MTV, Cuerden MS, Devereaux PJ, Abbasi SH, Hildebrand A, Lamontagne F, Lamy A, Noiseux N, Parikh CR, et al. Effect of methylprednisolone on acute kidney injury in patients undergoing cardiac surgery with a cardiopulmonary bypass pump: a randomized controlled trial. CMAJ 2019; 191: E247-E256.

5. Chunzhi G, Zunfeng L, Chengwei Q, Xiangmei B, Jingui $Y$. Hyperin protects against LPS-induced acute kidney injury by inhibiting TLR4 and NLRP3 signaling pathways. Oncotarget 2016; 7: 82602-82608.

6. Heinbockel L, Weindl G, Martinez-de-Tejada G, Correa W, Sanchez-Gomez S, Barcena-Varela S, Goldmann T, Garidel P, Gutsmann T, Brandenburg K. Inhibition of Lipopolysaccharide- and Lipoprotein-Induced Inflammation by Antitoxin Peptide Pep19-2.5. Front Immunol 2018; 9: 1704.

7. Zhang $Y, L i X$, Grailer JJ, Wang $N$, Wang $M$, Yao J, Zhong R, Gao GF, Ward PA, Tan DX, et al. Melatonin alleviates acute lung injury through inhibiting the NLRP3 inflammasome. J Pineal Res 2016; 60: 405-414.

8. Tanuseputero SA, Lin MT, Yeh SL, Yeh CL. Intravenous Arginine Administration Downregulates NLRP3 Inflammasome Activity and Attenuates Acute Kidney Injury in Mice with Polymicrobial Sepsis. Mediators Inflamm 2020; 2020: 3201635.

9. Liu R, Wang SC, Li M, Ma XH, Jia XN, Bu Y, Sun L, Yu KJ. An Inhibitor of DRP1 (Mdivi-1) Alleviates LPSInduced Septic AKI by Inhibiting NLRP3 Inflammasome Activation. Biomed Res Int 2020; 2020: 2398420.

10. Dong M, Yan BP, Liao JK, Lam YY, Yip GW, Yu CM. Rho-kinase inhibition: a novel therapeutic target for the treatment of cardiovascular diseases. Drug Discov Today 2010; 15: 622-629.

11. Schuppli CA. Decisions about the use of animals in research: Ethical reflection by animal ethics committee members. Anthrozoös 2011; 24: 409-425.

12. Hungaro TGR, Freitas-Lima LC, Gregnani MF, Perilhao MS, Alves-Silva T, Arruda AC, Barrera-Chimal J, Estrela GR, Araujo RC. Physical Exercise Exacerbates Acute Kidney Injury Induced by LPS via Toll-Like Receptor 4. Front Physiol 2020; 11: 768.

13. Abulizi $P$, Loganathan $N$, Zhao D, Mele $T$, Zhang $Y$, Zwiep $T$, Liu K, Zheng $X$. Growth Differentiation Factor15 Deficiency Augments Inflammatory Response and Exacerbates Septic Heart and Renal Injury Induced by Lipopolysaccharide. Sci Rep 2017; 7: 1037.

14. Ahmad A, Gero D, Olah G, Szabo C. Effect of endotoxemia in mice genetically deficient in cystathionine-gamma-lyase, cystathionine-betasynthase or 3-mercaptopyruvate sulfurtransferase. Int $J$ Mol Med 2016; 38: 1683-1692.

15. Jang $W Y$, Jung JK, Lee DK, Han SB. Intraoperative hypotension is a risk factor for postoperative acute kidney injury after femoral neck fracture surgery: a retrospective study. BMC Musculoskelet Disord 2019; 20: 131.

16. Rittirsch D, Huber-Lang MS, Flierl MA, Ward PA. Immunodesign of experimental sepsis by cecal ligation and puncture. Nat Protoc 2009; 4: 31-36.

17. Wu $M$, Chen $W, Y u X$, Ding $D$, Zhang $W$, Hua $H, X u M$, Meng $X$, Zhang $X$, Zhang $Y$, et al. Celastrol aggravates LPS-induced inflammation and injuries of liver and kidney in mice. Am J Transl Res 2018; 10: 2078-2086.

18. Wang $Y$, Zhang $H$, Yang $Z$, Miao $D$, Zhang $D$. Rho Kinase Inhibitor, Fasudil, Attenuates Contrast-induced

Trop J Pharm Res, October 2021; 20(10): 2061 
Acute Kidney Injury. Basic Clin Pharmacol Toxicol 2018; 122: 278-287.

19. Xie F, Lei J, Ran M, Li Y, Deng L, Feng J, Zhong Y, Li J. Attenuation of Diabetic Nephropathy in Diabetic Mice by Fasudil through Regulation of Macrophage Polarization. J Diabetes Res 2020; 2020: 4126913.

20. Sun Z, Ma Y, Chen F, Wang S, Chen B, Shi J. Artesunate ameliorates high glucose-induced rat glomerular mesangial cell injury by suppressing the TLR4/NF-kappaB/NLRP3 inflammasome pathway. Chem Biol Interact 2018; 293: 11-19.

21. Sharawy MH, Serrya MS. Pirfenidone attenuates gentamicin-induced acute kidney injury by inhibiting inflammasome-dependent NLRP3 pathway in rats. Life Sci 2020; 260: 118454.

22. Niu X, Yao Q, Li W, Zang L, Li W, Zhao J, Liu F, Zhi W. Harmine mitigates LPS-induced acute kidney injury through inhibition of the TLR4-NF-kappaB/NLRP3 inflammasome signalling pathway in mice. Eur $J$ Pharmacol 2019; 849: 160-169.

23. Han W, Ma Q, Liu Y, Wu W, Tu Y, Huang L, Long $Y$, Wang $W$, Yee $H$, Wan $Z$, et al. Huangkui capsule alleviates renal tubular epithelial-mesenchymal transition in diabetic nephropathy via inhibiting NLRP3 inflammasome activation and TLR4/NF-kappaB signaling. Phytomedicine 2019; 57: 203-214. 